\title{
CAMA
}

Centre for Applied Macroeconomic Analysis

\section{Has Foreign Growth Contributed to Stagnation and Inequality in Japan?}

\section{CAMA Working Paper 21/2016 May 2016}

Kazuki Tomioka

University of Western Australia

Rod Tyers

University of Western Australia and

Centre for Applied Macroeconomic Analysis, ANU

\section{Abstract}

This paper examines the contributions of foreign growth (particularly in China), on Japan's domestic economic performance and inequality. While the standard approach to external sources of inequality has emphasized transmission through trade and labor markets, here the emphasis is on financial flows. We begin by exploring this link using a three factor, three sector, two-region dynamic computable general equilibrium model (CGE), in which the regions are interlinked by both trade and financial flows. To provide an empirical perspective, a lag-augmented vector autoregression (LA-VAR) and a sign restricted vector autoregression (Sign restricted VAR) are estimated. We find convincing evidence through numerical simulations that strong growth in a near neighbor not only retards domestic performance but also raises home inequality. Empirical results suggest that growth in China has a significant delayed effect in aggravating Japanese inequality and its importance in explaining Japanese inequality increases in magnitude over time. 


\section{Keywords}

Japanese inequality, Foreign growth, Stagnation, Financial linkages, CGE, Lag augmented, Sign restriction, VAR.

\section{JEL Classification}

C32, C68, E25, F21, F41, F60

\section{Address for correspondence:}

(E) cama.admin@anu.edu.au

ISSN 2206-0332

The Centre for Applied Macroeconomic Analysis in the Crawford School of Public Policy has been established to build strong links between professional macroeconomists. It provides a forum for quality macroeconomic research and discussion of policy issues between academia, government and the private sector.

The Crawford School of Public Policy is the Australian National University's public policy school, serving and influencing Australia, Asia and the Pacific through advanced policy research, graduate and executive education, and policy impact. 


\title{
Has Foreign Growth Contributed to Stagnation and Inequality in Japan?
}

\author{
Kazuki Tomioka* \\ University of Western Australia
}

Rod Tyers ${ }^{\dagger \dagger}$

University of Western Australia \&

Centre for Applied Macroeconomic Analysis, Australian National University

Initial version: October 21, $2015^{\S}$

This version: April 17, 2016

\begin{abstract}
This paper examines the contributions of foreign growth (particularly in China), on Japan's domestic economic performance and inequality. While the standard approach to external sources of inequality has emphasized transmission through trade and labor markets, here the emphasis is on financial flows. We begin by exploring this link using a three factor, three sector, two-region dynamic computable general equilibrium model (CGE), in which the regions are interlinked by both trade and financial flows. To provide an empirical perspective, a lag-augmented vector autoregression (LA-VAR) and a sign restricted vector autoregression (Sign restricted VAR) are estimated. We find convincing evidence through numerical simulations that strong growth in a near neighbor not only retards domestic performance but also raises home inequality. Empirical results suggest that growth in China has a significant delayed effect in aggravating Japanese inequality and its importance in explaining Japanese inequality increases in magnitude over time.
\end{abstract}

JEL Classification: C32, C68, E25, F21, F41, F60

Keywords: Japanese inequality, Foreign growth, Stagnation, Financial linkages, CGE, Lag augmented, Sign restriction, VAR

\footnotetext{
*Business School, University of Western Australia. Email:kazuki.tomioka@uwa.edu.au

${ }^{\dagger}$ Business School, University of Western Australia and Centre for Applied Macroeconomic Analysis (CAMA), Australian National University. E-mail: rod.tyers@uwa.edu.au

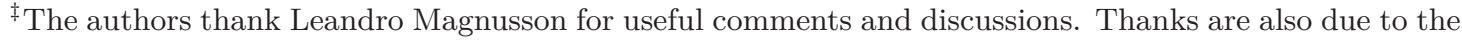
participants at a UWA research findings seminar and to Michael Jetter, Chris Parsons and Luciana Fiorini for useful comments on an earlier draft. The usual caveats apply.

${ }^{\S}$ An earlier version was submitted towards the Bachelor of Economics (Honours) degree at the University of Western Australia with the title 'Openness, Stagnation and Inequality in Japan: A New Perspective'.
} 


\section{Introduction}

The empirics of the relationship between income inequality and economic growth have been a popular research focus since Kuznets (1955) but a recent resurgence has followed the assertions by Piketty (2014) that inequality in industrialized counties has been rising as a consequence of laws that link inequality and growth performance. This paper contributes to that literature indirectly, by focusing on inequality in a focus country, namely Japan, and the link to comparative growth outside it. The standard approach to external sources of inequality has emphasized transmission through trade and labor markets. ${ }^{1}$ Here the emphasis is on financial flows that facilitate the diversion of investment to foreign economies that offer higher returns, sustaining home capital income but causing home labor markets to stagnate. In Japan's case the obvious external investment opportunities are in nearby China, the impacts of whose rapid expansion have been shown to be net welfare improving abroad but to cause distributional stress (Tyers, 2015; Tyers, 2016).

By comparison with other advanced regions, Japan might reasonably be regarded as oriented toward social equality. Indeed, commitments to social harmony and 'jobs for life' were once seen as driving the comparatively efficient Japanese economy of the 1960s to the 1980s (Tachibanaki, 2005). To establish the trends in Japanese inequality, we first compare measured Japanese income concentration with other industrialized countries using the data from the World Top Income Database. We find that, while income concentration in most other countries increases from the early 1980s, Japan's inequality neither increases as early nor as severely as other industrialized countries, and its transition path is the smoothest. We then shift our focus and draw connections between Japan's economic stagnation and its coincident inequality, linking this to the rise of China, claiming that there is a role in Japan's comparative stagnation for China's simultaneous rise, as hypothesized by Tyers (2012).

To support this claim, we first offer numerical simulations by formulating a dynamic model of two regional economies that are interlinked by both trade and financial flows. The model simulations confirm that both comparative stagnation and increased inequality could stem from an external growth surge in the presence of financial openness. The accelerating region offers high rates of return on investment outside the focus economy, curtailing domestic investment while boosting the foreign sourced portion of the income accruing to Japanese investors (capital owners). Slower domestic net capital growth then reduces the domestic marginal product of labor and slows labor demand, causing real wages and overall domestic performance to stagnate.

Having confirmed numerical support for this transmission mechanism we proceed to test it empirically, by first estimating a lag-augmented vector autoregression (LA-VAR

\footnotetext{
${ }^{1}$ This literature dates back into the early 1990s. For recent contributions, see Haskel et al. (2012) and Helpman et al. (2010).
} 
hereafter) to conduct Granger causality tests to infer whether Chinese growth has impacted Japan's inequality. To further complement the numerical simulation results, we then estimate a sign restricted vector autoregression (VAR hereafter) to identify a series of structural Chinese growth shocks and quantify the magnitude with which these affect Japan's inequality. These quantify the contribution of Chinese growth to inequality in Japan via impulse response functions (IRF hereafter) and forecast error variance decompositions (FEVD hereafter). Together with the numerical simulations, these methods allows us to evaluate and analyze the effects of foreign growth on Japan's inequality qualitatively and quantitatively.

The section to follow offers a brief review of the growth and inequality literature as it applies to Japan. Section 3 then documents financial and trade interdependence between Japan and China and the two-region growth model and its simulations are presented in Section 4. Our empirical methods are introduced in Section 5 and the data used and model specifications are detailed in Section 6. Results are then presented in Section 7. Conclusions are offered in Section 8.

\section{Growth-inequality dichotomy in Japan}

The classical Kuznets (1955) 'inverted U' hypothesis implies that inequality first increases and subsequently decreases during the process of economic development. While this pattern emerges as an empirical regularity, it does not explain much of variation in inequality across countries (Barro, 2000). Indeed, a recent survey by Ostry et al. (2014) suggests that inequality actually foster's economic growth. At the microeconomic level, inequality is 'healthy' since it provides incentives for greater effort and human capital acquisition (Okun, 1975; Lazear and Rosen, 1981). Yet severe inequality can aggravate the health or human capital of the poor, which can retard economic growth, while social segmentation impairs the preparedness of individuals and groups to provide public goods (Alesina and Perotti, 1996; Stiglitz et al., 2009).

Here we review the history of income concentration in Japan, comparing it with the experiences of other industrialized countries. Emphasis is given to the changes in Japan's inequality pattern since the commencement of its 'lost decades'. Drawing on income tax statistics, Piketty (2014) claims that inequality in industrialized countries have been rising since the 1980s and that this trend can be attributed to a failure of capital returns to diminish sufficiently and that real rates of return on capital have been larger than economic growth rates, even in periods of comparatively rapid capital accumulation.

[Figure 1 here]

From the World Top Income Database we draw the data in Figure 1. It indicates that, by comparison with the top percentile income share in other industrialized countries, 
Japan's income concentration was stable into the 1990s. Other regions had a declining trend in this period that is not present in these Japanese data. In the other advanced economies there is then a rise in inequality since the 1980s. Several explanations have been offered for this. Most fundamental is the globalization story, which begins with increased financial mobility internationally. Since the abolition of the Bretton-Woods agreement the mobility of financial capital internationally has increased; aided by technological improvements in information and communication technologies, allowing the diversification of investment globally. Moreover, financial globalization facilitates the efficient international allocation of capital and promotes international risk sharing. ${ }^{2}$

In association with financial integration, the period saw the opening of capital-poor, labor abundant, previously autarkic economies, including China. This greatly expanded the supply of labor to the integrated global economy, thus enhancing labor competition while offering opportunities for capital to move abroad from the advanced economies and take advantage of relative capital scarcity in these economies. The consequence has been wage restraint in the advanced economies, ${ }^{3}$ along with capital returns that are higher than would have been available otherwise (Wood, 1994; Tyers, Duncan, et al., 1999). Moreover, the associated rise in multinational business saw opportunities to reduce average tax rates on capital income (Feldstein, 1995; Lindsey, 1987). ${ }^{4}$ Piketty's complementary explanations for these rises in inequality are the failure of capital returns to diminish and real rates of return on capital that have been larger than economic growth rates, even in periods of comparatively rapid capital accumulation.

Japan is not only unique amongst the advanced economies in avoiding the decline in inequality to 1970, it also failed to exhibit the subsequent rise in inequality associated with this globalization process. Moriguchi and Saez (2008) argue that such supply-side effects did not occur in Japan even though it also reduced its marginal tax rate by $20 \%$ for top $0.1 \%$ of income earners after 1980, as did the US. They instead claim that Japan's unique internal labor market, emphasis on firm-specific human capital, and hence the absence of competitive markets for corporate executives, prevented a rise in income concentration from reduced marginal tax rates. The general notion that Japan is oriented toward social equality, as suggested by Tachibanaki (2005), can be observed in Table 1, which shows the Gini coefficients pre-tax and post-tax and transfers, prior to Japan's notorious stagnation period. In comparison with other industrialized countries, including the Scandinavian welfare state

\footnotetext{
${ }^{2}$ Increased financial flows, in the form of both foreign direct and portfolio investment, have been associated elsewhere with income concentration in both advanced and emerging market economies (Freeman, 2010).

${ }^{3}$ A large literature documents this trend, commencing with empirical work on labor markets by Berman et al. (1994), Bound and Johnson (1992), Feenstra and Hansen (1995), and Leamer (1996), theory and modelling by Krugman (1995), Tyers and Yang (1997), and Tokarick (2005) and recent modelling by Haskel et al. (2012), Harris and Robertson (2013), and Autor et al. (2013).

${ }^{4}$ The further global distributional effects of the competing explanation for rising labor inequality, namely labor saving technical change, are explored in the presence of capital-skill complementarity by Tyers and Yang (1997) and Winchester and Greenaway (2007).
} 
Table 1: Gini Coefficients in Advanced Countries

\begin{tabular}{lccccccc}
\hline & \multicolumn{3}{c}{ Pre-Tax and Transfers } & & \multicolumn{3}{c}{ Post-Tax and Transfers } \\
\cline { 2 - 3 } \cline { 7 - 8 } Country & Rank & Year & Gini & & Rank & Year & Gini \\
\hline Belgium & 1 & 1988 & 0.273 & & 2 & 1987 & 0.260 \\
Canada & 5 & 1987 & 0.374 & & 7 & 1987 & 0.305 \\
Finland & 6 & 1987 & 0.379 & & 1 & 1987 & 0.255 \\
France & 10 & 1984 & 0.417 & & 8 & 1984 & 0.311 \\
Germany & 7 & 1984 & 0.395 & & 4 & 1984 & 0.277 \\
Ireland & 13 & 1987 & 0.461 & & 11 & 1987 & 0.341 \\
Italy & 4 & 1986 & 0.361 & & 9 & 1986 & 0.321 \\
Japan & 2 & 1989 & 0.317 & & 6 & 1985 & 0.298 \\
Netherlands & 3 & 1987 & 0.348 & & 3 & 1987 & 0.266 \\
Sweden & 12 & 1987 & 0.439 & & 5 & 1987 & 0.281 \\
Switzerland & 8 & 1982 & 0.407 & & 12 & 1982 & 0.346 \\
United Kingdom & 11 & 1986 & 0.428 & & 10 & 1986 & 0.323 \\
United States & 9 & 1986 & 0.411 & & 13 & 1986 & 0.347 \\
\hline
\end{tabular}

Note: Ranks are ordered from lowest income Gini coefficient to the highest.

Source: Nishizaki et al. (1998), implemented from Moriguchi and Saez (2008)

countries that have extensive social security systems, Japan seems to rank just behind these countries in the equality of post-tax disposable income and second prior to tax and transfers indicating smaller role of welfare system in Japan. This suggests Japanese society was naturally equal, with unique internal labor market structures, and along the lines proposed by Moriguchi and Saez (2008).

[Figure 2 here]

But this changed with the financial bust in the early 1990s, as indicated in Figure 1, which also draws on the World Top Income Database and depicts the mean incomes of the top one percentile and the bottom 90 percentile. Initially, cuts to the incomes of the wealthy reduced inequality. During the 'lost decades' that commenced in the 1990s, however, Japan's income concentration rose significantly. Its post-tax and transfers Gini coefficient and its disposable income decile ratio rose above the OECD average as depicted in Figure 3. The trend has diverged since early 1990s, coinciding with Japan's stagnation.

[Figure 3 here]

Despite this apparent association between Japan's stagnation and its inequality, few studies have examined the linkages between Japanese inequality and macroeconomic conditions. Saiki and Frost (2014) report that Japan's inequality was affected after 2000, when the Bank of Japan pursued unconventional monetary policy. Likewise, while adopting similar econometric methods, Suzuki et al. (2014) analyze the linkages between Japan's macro-variables and inequality. They use impulse response analysis and historical decomposition based on their estimated VAR, finding statistically significant change in inequality 
due to shocks to stock prices, industrial production and the policy rate during Japan's episodes of boom and bust between the 1980s and 2008. Yet these studies ignore what we believe was a key determinant of the change in Japan's macro performance in these years, namely the growth take-off in neighboring China.

\section{The significance of China's growth surge for Japan}

It is widely known and accepted that Japan's economy stagnated from the 1990s, with numerous explanations offered, emphasizing demand side (Horioka, 2006) and supply side Hayashi and Prescott (2002) factors. Here, we revisit a hypothesis proposed by Tyers (2012). This emphasizes the role of Chinese growth, which accelerated after macroeconomic policy reforms around 1994 and surged again after its WTO accession in 2001 to unprecedented levels for so large a country. Given China's proximity to Japan and its economic complementarity in this period, old political enmities aside, the expansion of economic interdependence between the two countries was inevitable. While this took the form of expanded trade, of most interest here is that Chinese growth raised returns on investment there relative to those in Japan, creating a yield spread which saw the diversion of investment away from Japan's domestic economy and in favor of China. This diversion of investment complements both the demand and supply side perspectives on Japanese stagnation, since it explains the decline in net domestic investment demand on the one hand while curtailing capital renewal and so cutting productivity growth.

[Figure 4 here]

The significance of China's growth surge can be seen from Panel (a) of Figure 4, which shows the composition of global GDP. China's contribution expands, while Japan's contracts, leading to a change in the composition of global GDP between the two nations while their combined share in global output remained roughly constant since the 1990s. It is our argument that Japan's stagnation was prolonged due to the diversion of domestic and foreign investment away from Japan to neighboring China, where the rate of return was higher. The expansion of trade between the two nations took the form of labor intensive imports by Japan and capital intensive exports to China, thus favoring capital in Japan and labor in China. As Panel (b) in Figure 4 shows, China's share of Japan's exports and imports expanded significantly. But the investment effect also ensured that Japanese savers continued to accrue income and capital gains abroad, while the lack of capital and capital investment growth at home saw the stagnation of wages domestically. It is therefore further proposed that China played a role in increasing Japan's inequality.

[Figure 5 here] 
To get an idea as to the scale of the Japanese asset stock held abroad we have estimated its non-housing 'wealth' after 1980, as depicted in Figure 5. As expected, it shows that the portion of aggregate wealth that is held abroad rose rapidly after the mid-1990s. We suggest that this reflects the redirection of domestic saving into foreign assets as home returns fell following the collapse of the bubble economy and with the continuing demographic contraction. At the same time, Japan's comparatively high costs and corporate tax rates have provided incentives to off-shore much of its once efficient manufacturing industry. While wage rates are clearly lower in China than in Japan, the data in Table 2 suggest that the rate of corporate tax in Japan was the highest among the industrialized countries during the period of 1990 to 1995, second only to Germany.

Table 2: Effective Corporate Tax Rates in Advanced Economies (\%)

\begin{tabular}{lrrrrrrrr}
\hline Countries & 1981 & 1985 & 1990 & 1995 & 2000 & 2005 & 2010 & 2014 \\
\hline Australia & 46.0 & 46.0 & 39.0 & 36.0 & 34.0 & 30.0 & 30.0 & 30.0 \\
Canada & 50.9 & 49.4 & 41.5 & 42.9 & 42.4 & 34.2 & 29.4 & 26.3 \\
France & 50.0 & 50.5 & 42.0 & 36.7 & 37.8 & 35.0 & 34.4 & 34.4 \\
Germany & 60.0 & 60.0 & 54.5 & 55.1 & 52.0 & 38.9 & 30.2 & 30.2 \\
Japan & n.a. & n.a. & 50.0 & 50.0 & 40.9 & 39.5 & 39.5 & 34.6 \\
United Kingdom & 52.0 & 40.0 & 34.0 & 33.0 & 30.0 & 30.0 & 28.0 & 21.0 \\
United States & 49.7 & 49.8 & 38.7 & 39.6 & 39.3 & 39.3 & 39.2 & 39.1 \\
\hline
\end{tabular}

Source: OECD and Ministry of Finance, Japan

\section{Numerical theory}

In order to examine the effects of Chinese growth on Japan's economy and its inequality, we develop a simple two region dynamic general equilibrium model. This model applies conventional theory to a stylized numerical representation of Japan and a foreign region like China. The two regional households trade in goods and exchange investments. Indeed, each manages a portfolio of physical capital assets at home and abroad that is rebalanced annually depending on rates of return. Model simulations allow the qualitative assessment of the proposed mechanism by which foreign growth influences domestic inequality while at the same time suggesting structural assumptions and hypotheses that are subject to empirical testing in subsequent sections.

Each region has three industries: agriculture, manufacturing and services, employing Cobb-Douglas technology. The factors are raw labor, $L$, capital, $K$, which includes human capital and land, A. Dynamic simulations are departures from a baseline steady state zero growth path in which investment is at break-even level in both regions. 


\subsection{Supply Side}

In both regions, the production functions take the Cobb-Douglas form

$$
\begin{aligned}
Q_{i t} & =\Gamma_{i t} L_{i t}^{\beta_{i L}} K_{i t}^{\beta_{i K}} A_{i t}^{\beta_{i A}}, \\
& =\Gamma_{i t} \prod_{j=1}^{3} \Psi_{j i t}^{\beta_{j i}} \quad \forall i, \quad \sum_{j=1}^{e} \beta_{j i}=1,
\end{aligned}
$$

where the 3 sectors are indexed by $i=$ (agriculture, manufacturing, services) and the 3 primary factors are indexed by $j=(L, K, A)$. The coefficient $\Gamma$ governs total factor productivity (TFP hereafter) in each sector. The cost minimization subject to (1) in each industry, yields the set of unit factor demands, $\underline{\psi}_{i t}=\left[\psi_{j i t}\right]=\left(l_{i t}, k_{i t}, a_{i t}\right)$

$$
\psi_{j i t}=\frac{1}{\Gamma_{i t}}\left(\frac{\beta_{j i}}{w_{j t}}\right)^{\left(1-\beta_{j i}\right)} \prod_{k \neq j}\left(\frac{w_{k t}}{\beta_{k i}}\right)^{\beta_{k i}}, \quad \forall i, j .
$$

Note that each of these unit factor demands depends only on the factor shares, denoted by $\beta$; and the unit factor rewards $\underline{w}=\left[w_{j}\right]=\left(w_{L}, w_{K}, w_{A}\right)$, each denoting wage, capital rental rate and land rental rate respectively. Price taking behavior and constant returns to scale give rise to the standard conditions from which the Stolper and Samuelson (1941) relationship emerges

$$
p_{i t}=\sum_{j=1}^{3} \psi_{j i t} w_{j t}, \quad \forall i
$$

where $w_{j}$ is the unit factor rewards for all three factors as before. Both labor and land are permanently exogenous and thus are subject to the resource constraints

$$
\bar{L}_{t}=\sum_{i=1}^{3} l_{i t} Q_{i t}, \quad \bar{A}_{t}=\sum_{i=1}^{3} a_{i t} Q_{i t} .
$$

The capital stock is endogenous and it accumulates in each region through time. Nonetheless its use in any year must similarly be the sum of all industry uses

$$
K_{t}=\sum_{i=1}^{3} k_{i t} Q_{i t}
$$

and follows the accumulation process

$$
K_{t+1}=\left(1-\delta_{t}\right) K_{t}+I_{t}
$$

where $I_{t}$ is the investment term with gestation lag of a year and $\delta$ is the capital depreciation rate. To emphasize the international flows of financial transactions, investment is financed in each region by the issuance of region-specific and differentiated assets, which are purchased from the savings of the households in both regions. These assets represent a claim over one unit of capital stock of the issuing region. 


\subsection{Demand Side}

In each region, a representative household has a portfolio manager. For the home region, in each year, this manager chooses the shares of the region's current saving that are committed to the assets of the home region, denoted by $\theta_{h}$ and of the foreign region, denoted by $\theta_{f}$. Hence the home region yield function can be expressed as

$$
\begin{aligned}
\max _{\theta_{h t}, \theta_{f t}} R_{h} & =\left[\phi_{h}\left(r_{h t}^{e}\right)^{\alpha_{h}} \theta_{h t}^{-\rho_{h}}+\phi_{f}\left(r_{f t}^{e}\right)^{\alpha_{h}} \theta_{f t}^{-\rho_{h}}\right]^{-\frac{1}{\rho_{h}}}, \\
\text { s.t. } \quad 1 & =\theta_{h t}+\theta_{f t},
\end{aligned}
$$

where $\phi$ is the coefficients that are calibrated from the initial saving shares; $r_{h}^{e}$ and $r_{f}^{e}$ are the expected rates of return on home and foreign assets; and $\alpha_{h}$ is the 'return chasing' elasticities. In essence, (7) implies that the home portfolio manager maximizes a constant elasticity of substitution (CES hereafter) composite of terms in shares and expected rates of return that allows for imperfect substitutability between the assets of each regions due to exogenous risk and regional financial market idiosyncrasies. Hence, yield is driven by the variable coefficients in the CES composite yield function.

The first order conditions give the home region demands for home asset

$$
\begin{aligned}
B_{h t} & =S_{h t} \theta_{h t} \\
& =S_{h t}\left\{\frac{\left[\phi_{h}\left(r_{h t}^{e}\right)^{\alpha_{h}}\right]^{\sigma_{h}}}{\left[\phi_{h}\left(r_{h t}^{e}\right)^{\alpha_{h}}\right]^{\sigma_{h}}+\left[\phi_{f}\left(r_{f t}^{e}\right)^{\alpha_{h}}\right]^{\sigma_{h}}}\right\},
\end{aligned}
$$

and home region demands for foreign asset given by

$$
\begin{aligned}
B_{f t} & =S_{h t} \theta_{f t} \\
& =S_{h t}\left\{\frac{\left[\phi_{f}\left(r_{f t}^{e}\right)^{\alpha_{h}}\right]^{\sigma_{h}}}{\left[\phi_{h}\left(r_{h t}^{e}\right)^{\alpha_{h}}\right]^{\sigma_{h}}+\left[\phi_{f}\left(r_{f t}^{e}\right)^{\alpha_{h}}\right]^{\sigma_{h}}}\right\},
\end{aligned}
$$

where $S_{h}$ is the home region's total saving and $\sigma_{h}=1 / 1+\rho_{h}$ is the home region's implied elasticity of substitution between home and foreign assets. ${ }^{5}$ Hence the investment levels in the home region is

$$
I_{h t}=B_{h t}+B_{f t} .
$$

Expectations over rates of return is adaptive with $\lambda$ denoting the lagged adjustment term. The rate of return expectation for assets in the both regions are formulated following

$$
r_{t+1}^{e}=r_{t}^{e}+\lambda\left(r_{t}-r_{t}^{e}\right)
$$

which directly enters into the yield function in (7).

The demand side centers on the collective utility function in gross consumption, of both

\footnotetext{
${ }^{5}$ Note that a parallel maximization problem and set of asset demands applies for the foreign region, $f$.
} 
home and imported varieties. Here, for each collective household, Cobb-Douglas preferences are applied. For the home household these are expressed as

$$
U_{h t}=\prod_{i=1}^{3} C_{h i t}^{\gamma_{h i}} .
$$

Here, the home economy vector of consumption levels that are composites of home and foreign varieties is $\underline{C}_{h t}=\left[C_{h t}^{i}\right]=\left(C_{h}^{A g}, C_{h}^{M}, C_{h}^{S}\right)$. When the home collective household maximizes this utility subject to its budget constraint we obtain the Cobb-Douglas Marshallian demand functions for these composites

$$
C_{h i t}=\gamma_{h i} \frac{Y_{h t}^{N}}{P_{h i t}}
$$

where the $\gamma_{i}$ is the expenditure share; $Y^{N}$ is the level of regional gross national product (GNP hereafter); and $P_{h i}$ is the home composite price, combining home and imported varieties of generic product $i$, respectively produced from the sectors $i$, which entered the production function. The Armington (1969) separability assumption is made regarding regional differentiation of products, such that the consumer first makes a choice as to how to divide expenditure between the three generic goods in (12). Then, separately, the household minimizes the cost of a generic bundle of home and foreign varieties subject to CES aggregation constraint. For the home household and product $i$, it can be expressed as

$$
C_{h i t}=\left[\eta_{h i} c_{h i t}^{-\tau}+\eta_{f i} c_{f i}^{-\tau}\right]^{-\frac{1}{\tau}}
$$

The elasticity of substitution between these is then $\kappa=1 / 1+\tau$ and the base period shares of each in total expenditure on the composite in home region are

$$
s_{C h i}=\eta_{h i}^{\kappa}, \quad s_{C f i}=\eta_{f i}^{\kappa} .
$$

The resulting Marshallian demands for the varieties in the home region are

$$
c_{h i t}=s_{h i} C_{h i t}\left(\frac{p_{h i t}}{P_{h i t}}\right)^{-\kappa}, \quad c_{f i t}=s_{f i} C_{f i t}\left(\frac{p_{f i t}}{P_{f i t}}\right)^{-\kappa},
$$

where the composite price of the generic product $i$ in the home region is

$$
P_{h i}=\left[\eta_{h i}^{\kappa} p_{h i}^{1-\kappa}+\eta_{f i}^{\kappa} p_{f i}^{1-\kappa}\right]^{\frac{1}{1-\kappa}}
$$

Product balance constraints then determine the distribution of consumption and trade, thus for the home region we require

$$
Q_{h i}=c_{h i}+c_{f i}, \quad \forall i
$$

There are no indirect taxes so that GDP for both regions is the same as GDP at factor cost 
and thus it can be expressed in the home region as

$$
Y_{h t}=w_{h A t} \bar{A}_{h}+w_{h L t} \bar{L}_{h}+w_{h K t} K_{h t} .
$$

The corresponding level of GNP, in the home region is

$$
Y_{h t}^{N}=w_{h A t} \bar{A}_{h}+w_{h L t} \bar{L}_{h}+w_{h K t} K_{h t}+w_{f K t} K_{f t}
$$

where $K_{h}$ and $K_{f}$ are the home region's capital holdings at home and in the foreign region. Lastly, exogenous saving rates, $s$ in both regions are held constant. Representing the total saving levels in the home region required for allocations in (8) and (9) is

$$
S_{h t}=s_{h} Y_{h}^{N}
$$

\subsection{Numerical Simulations}

To represent the effects of accelerating growth in China, the foreign region, shocks are applied such that the foreign manufacturing sector has productivity growth that is faster by $1 \%$ per year. No shocks are imposed in the home region. ${ }^{6}$

[Figure 6 here]

The effects on the trends in output and asset demands are indicated in Figure 6. Panel (a) shows that, while the foreign region grows exponentially, the home economy declines in real terms as a consequence. Panel (b) indicates that this stems from real investment in the foreign region and declining investment at home, while Panel (c) digests this down to rising home demand for foreign assets and declining foreign demand for home assets. The effects on wealth and its distribution are then shown in Panel (d), the highlight being the substitution of foreign for domestic assets in the home portfolio.

[Figure 7 here]

The effects of foreign growth in income and its distribution are delineated in Figure 7. In it, Panel (a) shows that aggregate real income by GNP rises rapidly in the foreign region however, the fall in real GDP indicated in Panel (a) of Figure 6 is not matched by a corresponding fall in GNP for the home region. This is because of the comparatively high and rising rate of return on foreign investment, shown in Panel (b), the growth of home region holdings of foreign assets and hence the expansion of net factor income from abroad that accrues to capital owners in the home region, shown in Panel (c). The income of home capital owners grows from this source and overall. That from land rents grows

\footnotetext{
${ }^{6}$ The abstraction of a two-region model is constraining here. In fact, China's expanded imports, particularly of agricultural products, come from other regions of the world and not from Japan. But the two region framework offers the most elemental characterisation of the financial effects of the foreign growth surge, which is our point of emphasis.
} 
too, though it is comparatively small. With stable home GNP, it follows that labor income must decline. The resulting increased income dispersion is indicated in Panel (d).

While these distributional impacts are significant and they are sourced in the availability of high returning investments abroad, the model also captures trade effects. Home land rents increase along with capital income since the foreign manufacturing growth crowds out its other tradable activities, thus requiring imports and so there is a terms of trade effect in both regions favoring the tradable non-manufacturing, agricultural sector. This induces a shift in resources toward this sector at home and so raises income from land. In the case of Japan, this effect is necessarily small. Most importantly, while foreign growth makes land and capital owners better off, the implications for wage incomes in the home region turn out to be negative in absolute terms. The decline in labor income arises from a shift of production in the manufacturing sector from the home region to the foreign region. This simulation result shows a similar pattern to Figure 2, which illustrates a decline in absolute terms of income for the bottom $90 \%$ of the population, where their majority of earnings originate from labor wages.

\subsection{Transmission mechanism}

To clarify and summarize the results provided by the numerical simulations on the role of foreign growth to home inequality, consider the flowchart in Figure 8.

[Figure 8 here]

The simplified mechanism, by which foreign productivity increases transmit to home inequality, is through foreign investment and capital income repatriation. The result is a higher capital to labor income ratio in the home economy stemming from the home portfolio manager's incentive to invest in the foreign region. A shock to TFP in the foreign region leads to increases in both GNP and the rate of return in the foreign region. Observing the higher rate of return, the home portfolio manager invests some home savings in the foreign assets. Such substitution in investment yields net factor income from abroad, which feeds back into the home capital income component of GNP. This leads to a declining capital stock at home and as a reduced marginal product of labor, wage income therefore declines. This vicious cycle for the home region and positive cycle for the foreign region continues, worsening inequality over time.

\section{Empirical methods}

Here we turn to the available data with a view to assessing the scale of the contribution of foreign growth to Japan's inequality expansion during its lost decades. We do this in two stages, first through augmented Granger causality test following Toda and Yamamoto 
(1995)'s LA-VAR approach and second through IRF and FEVD analyses by estimating a sign restricted VAR using the same set of variables as in the LA-VAR.

The procedural steps required in estimating a LA-VAR are first, to determine the maximal order of integration of variable that enter the VAR endogenously, through unitroot tests. Next, we estimate a reduced form VAR in levels with a constant with the number of lags determined by the information criterion plus the maximal order of integration in the variables. This overcomes the possibility that spurious causality can emerge when estimating a non-stationary VAR via OLS, due to non-standard asymptotic distributions with unobservable 'nuisance parameters' (Toda and Phillips, 1993; He and Maekawa, 2001). Then, we conduct the augmented Granger causality test by ignoring the coefficient matrices of the lagged vectors that were added of maximal order of integration as they were incorporated to control for the non-standard asymptotic distribution. Finally, we estimate a sign restricted VAR that reflects the identified transmission mechanism, with the emphasis on the financial channel; where we derive the sign restrictions from the directions of the simulation results in Section 4. This enables inference of the magnitude of the foreign growth effect on inequality in Japan.

A reduced form VAR with $m$ dimensions $Y_{t}=\left[y_{1 t}, y_{2 t}, \cdots, y_{m t}\right]^{\prime}$ and $p$ lags can be expressed as $\operatorname{VAR}(p)$ :

$$
Y_{t}=\Phi_{0}+\Phi_{1} Y_{t-1}+\Phi_{2} Y_{t-2}+\cdots+\Phi_{p} Y_{t-p}+\varepsilon_{t}
$$

where $Y_{t}$ is a vector of endogenous variables; $\Phi_{0}$ is a vector of constants; $\Phi_{i},(i=1,2, \cdots, p)$ are $m \times m$ vector of coefficients; and $\varepsilon_{t}$ is the vector of reduced form residuals with a variance-covariance matrix denoted by $\Sigma$, where $\Sigma=\mathbb{E}\left[\varepsilon_{t} \varepsilon_{t}^{\prime}\right]$. A series of structural shocks are recovered by specifying a matrix $\Omega$ such that

$$
\Omega \varepsilon_{t}=e_{t}
$$

where $\Omega$ is a $m \times m$ matrix of structural parameters given by the Cholesky decomposition of $\Sigma$; and $e_{t}$ is a vector of structural shocks that follow $e_{t} \sim \mathcal{N}(0,1)$ such that $\mathbb{E}\left[e_{t} e_{t}^{\prime}\right]=I$. Then, in order to identify the shock, $\Omega$ must satisfy

$$
\begin{aligned}
\Sigma & =\mathbb{E}\left[\varepsilon_{t} \varepsilon_{t}^{\prime}\right]=\Omega \mathbb{E}\left[e_{t} e_{t}^{\prime}\right] \Omega^{\prime}, \\
& =\Omega \Omega^{\prime} .
\end{aligned}
$$

The uninformative Normal-Wishart prior distribution is used to draw random samples of $\Phi$ and $\Sigma$ from their respective posterior distributions. Uhlig (2005) shows that $\operatorname{vec}(\Phi)$ and $\Sigma^{-1}$ then follow $\mathcal{N}\left(\operatorname{vec}(\hat{\Phi}), \hat{\Sigma} \otimes\left(X^{\prime} X\right)^{-1}\right)$ and $\mathcal{W}\left(\hat{\Sigma}^{-1} / N, N\right)$ respectively, where $\hat{\Phi}$ and $\hat{\Sigma}$ are OLS estimates; $\otimes$ denotes the Kronecker product; $X$ is the matrix of the explanatory variables; and $N$ is the sample size. Then, the structural shocks and matrix of contemporaneous relations among the endogenous variables are calculated from each draw by randomly 
generating the orthogonal matrix $Q$. Thus, (23) can be rewritten as

$$
e_{t}=\Omega Q^{\prime} Q \varepsilon_{t}=\Omega \tilde{\varepsilon}_{t}
$$

Likewise, (24) is

$$
\begin{aligned}
\Sigma & =\mathbb{E}\left[\Omega \tilde{\varepsilon}_{t} \tilde{\varepsilon}_{t}^{\prime} \Omega^{\prime}\right]=\mathbb{E}\left[\Omega Q^{\prime} Q \varepsilon_{t} \varepsilon_{t}^{\prime} Q^{\prime} Q \Omega^{\prime}\right], \\
& =\Omega \Omega^{\prime} .
\end{aligned}
$$

We closely follow Uhlig (2005)'s rejection method as implemented in Danne (2015) to recover structural shocks. Hence we concentrate on identifying the innovation corresponding to the Chinese growth shock by identifying a single column $\omega \in \mathbb{R}^{m}$ of $\Omega$ in (26), which is the impulse vector. Uhlig (2005) shows that $\omega$ is an impulse vector iff there is an m-dimensional vector of $w$ of unit length $(\|w\|=1)$, such that

$$
w=\tilde{\Omega} \omega
$$

where $\tilde{\Omega} \tilde{\Omega}^{\prime}=\Sigma$ is the Cholesky decomposition of $\Sigma$. Then, the impulse response $r_{\omega}(k)$ is given by

$$
r_{\omega}(k)=\sum_{i=1}^{m} w_{i} r_{i}(k)
$$

where $r_{i}(k) \in \mathbb{R}^{m}$ is the vector response at horizon $k$ to the $i$ th shock in a Cholesky decomposition of $\Sigma$.

\section{Data and specification}

As our interest is the period of correspondence between Japan's relative stagnation and China's adjacent rapid expansion, we apply the Zivot and Andrews (1992)'s unit root test with an endogenous structural break to real GDP for Japan and China, to identify the location of this coincidence. ${ }^{7}$ Following Zivot and Andrews (1992), three different models are considered, a model with intercept, ZA(A), a model with trend, ZA(B), and a model with both intercept and trend, $\mathrm{ZA}(\mathrm{C})$. The null is $H_{0}: \alpha=1$, suggesting the presence of a unit root and no structural change. The results indicate that the structural break for Japan occurs in the third quarter of 1989, while that for China occurs in the second quarter of 1993, by selecting ZA(C), a model with both the intercept and trend for both Japan and China. In each case, we reject the null that there is no structural break and unit root at the 5\% level of significance. These results are consistent with our intuition that Japan's stagnation commenced at the end of the 1980s and China's growth surge started with reforms to Chinese monetary policy and to its tax system that took effect in 1994

\footnotetext{
${ }^{7}$ The Chinese GDP series at quarterly frequency is only available since 1992 . To accurately identify the location of the possible structural change; we have decided to extend the series by linearly interpolating the annual series from 1980 to 1991.
} 
Table 3: Zivot-Andrews Test

\begin{tabular}{|c|c|c|c|c|c|c|}
\hline \multirow[b]{2}{*}{ Variable } & \multicolumn{2}{|c|}{ Model ZA(A) } & \multicolumn{2}{|c|}{ Model ZA(B) } & \multicolumn{2}{|c|}{ Model ZA(C) } \\
\hline & t-statistic & Break Point & t-statistic & Break Point & t-statistic & Break Point \\
\hline$Y_{j}$ & -3.77 & 1987Q2 & $-5.10^{* * *}$ & 1990Q3 & $-5.27^{* *}$ & 1989Q3 \\
\hline$\Delta^{1} Y_{j}$ & $-5.26^{* *}$ & 1991Q2 & $-4.44^{* *}$ & 1998Q1 & -5.30 & 1998Q1 \\
\hline$Y_{c}$ & $-4.60^{*}$ & 1984Q2 & $-4.69^{* *}$ & 1988Q2 & $-5.70^{* * *}$ & 1993Q2 \\
\hline$\Delta^{1} Y_{c}$ & -2.93 & 1990Q4 & -2.32 & 1993Q4 & -2.94 & 1990Q4 \\
\hline
\end{tabular}

Note: "***", “**" and "*" represent $1 \%, 5 \%$ and $10 \%$ level of significance respectively. $Y_{j}, Y_{c}$ respectively denotes Japan's real GDP and China's real GDP. $\Delta^{1}$ represent first order differences. Critical values are obtained from Zivot and Andrews (1992).

(Tyers, 2012). We conclude that the coincidence therefore commences in 1994, and so choose a sample period from the third quarter of 1993 to first quarter of 2014 .

To mimic the emphasis on financial channels in earlier Sections we estimate a VAR with five endogenous variables. While the order of exogeneity is irrelevant when estimating a sign restricted VAR; it is important when estimating a reduced form VAR to conduct the augmented Granger causality tests. Hence the endogenous variables in $Y_{t}$ in (22) are entered as follows

$$
Y_{t}=\left[\begin{array}{c}
g_{c, t} \\
\log \left(\text { Out }_{t}\right) \\
\log \left(\operatorname{In}_{t}\right) \\
r_{j, t} \\
\log \left(\text { Inequality }_{t}\right)
\end{array}\right],
$$

where $g_{c, t}$ is the real economic growth rate in China measured in percentage points per year; $\log$ (Out) is a $\log$ proxy for the outflow of investment from Japan to China obtained by weighting outbound factor income, as reported in Japan's financial and capital account, by the China share of exports from Japan; $\log (\mathrm{In})$ is a log proxy for the inflow of factor income from China to Japan obtained by weighting inbound factor income reported in Japan's financial and capital account by the China share of imports from China to Japan; $r_{j, t}$ is the yield of 10 year treasury bonds in Japan, measured in percentage points per year; and $\log$ (Inequality) is a proxy for inequality, defined as a log ratio between the sum of capital and mixed income with net factor income over aggregate income measured by the gross national product. ${ }^{8}$ All data are seasonally adjusted using X-13 Arima-Seats and are transformed by taking logarithms, except for the growth rate in China and the long bond yield in Japan, which remain unseasonalized and are entered in levels. The variables $\log \left(\right.$ Out $\left._{t}\right), \log \left(\operatorname{In}_{t}\right)$ and $\log \left(\right.$ Inequality $\left._{t}\right)$ are sourced from the balance of payments statistics

\footnotetext{
${ }^{8} \mathrm{~A}$ particular note must be made with our selection of weighting the financial and capital flows with China's share in Japan's exports and imports. Despite our efforts, we were unable to find the statistics on the composition of financial and capital account prior to 2005. Hence we have decided to approximate capital and financial flows by annual data on current account flows between Japan and China and linearly interpolate the series to quarterly frequency. Moreover, we have decided to weight the whole period by the same method for consistency.
} 
published by the Statistics Bureau of Japan and national accounts by the Cabinet Office, Japan. The growth rate in China, $g_{c, t}$, is obtained from the national accounts published by the National Bureau of Statistics, China and the long bond yield in Japan, $r_{j, t}$, is sourced from the interest rate database at the Ministry of Finance, Japan. The series for these variables are illustrated in Figure 9.

[Figure 9 here]

Relying on the conclusions made by Sims et al. (1990), we estimate a VAR in levels to preserve the degrees of freedom and to mitigate the loss of information, with one lag as suggested by the Bayesian information criterion and a constant. With this setup, we identify a series of Chinese growth shocks and set sign restrictions in a VAR consistent with the numerical simulations in Section 4. The sign restrictions are summarized in Table 4. The key variable inequality is unrestricted to test whether our inference from the numerical simulations are empirically consistent.

Table 4: Sign restrictions

\begin{tabular}{l|c}
\hline & China growth shock \\
\hline \hline China growth & + \\
\hline Outbound income & + \\
\hline Inbound income & + \\
\hline Japan long yield & - \\
\hline Inequality & \\
\hline
\end{tabular}

\section{$7 \quad$ Results}

The results of the augmented Granger causality test, following the implementation by Toda and Yamamoto (1995), are presented in Table 5. We reject the null of non-causality from Chinese growth at the $10 \%$ level, confirming the possibility of a behavioral link between $g_{c, t}$ and $\log \left(\right.$ Inequality $\left._{t}\right)$. This offer some support for the key hypothesis that China's growth has affected Japan's inequality. While this link is clear bivariately, we struggle to find evidence of causal links when Chinese growth is combined with estimated financial flows. A key reason for this is that there are, in reality, two causal steps. First high Chinese growth offers high rates of return which induce financial flows. Second, these financial flows add to domestic capital income while starving the home economy of investment and labor productivity growth. This complexity suggests the relative merit of the bivariate causality analysis. Beyond this, our data construction suffers from approximation bias in assembling the financial and capital account flows between Japan and China.

Also importantly, the numerical simulations from which our hypothesis stems, are constructed in such a way that foreign investment earnings are repatriated back to the home region on realisation. In reality, however, not all foreign earnings are repatriated. In 
fact, it is possible that high rates of corporate and income tax in Japan and comparatively weak capital gains taxation, cause firms to retain earnings, including earnings abroad. During the lost decades, such funds would then have been reinvested abroad at the higher foreign rate of return. This suggests a possible understatement of inequality as measured by the ratio of capital to aggregate income. This inference is true to the extent that 'wealth' that is owned abroad has been exponentially rising since the early nineties, as illustrated in Figure 5.

Table 5: Granger Causality Test

\begin{tabular}{lcc}
\hline \multicolumn{1}{c}{$H_{0}$} & $\chi^{2}$ statistic & p-value \\
\hline$g_{c, t} \stackrel{G}{\rightarrow} \log \left(\right.$ Inequality $\left._{t}\right)$ & 3.1 & 0.08 \\
$g_{c, t} \& \log \left(\right.$ Out $\left._{t}\right) \stackrel{G}{\rightarrow} \log \left(\right.$ Inequality $\left._{t}\right)$ & 4.4 & 0.11 \\
$g_{c, t} \& \log \left(\operatorname{In}_{t}\right) \stackrel{G}{\rightarrow} \log \left(\right.$ Inequality $\left._{t}\right)$ & 3.5 & 0.17 \\
$g_{c, t} \& r_{j, t} \stackrel{\rightarrow}{\nrightarrow} \log \left(\operatorname{Inequality~}_{t}\right)$ & 2.0 & 0.19 \\
$g_{c, t}, \log \left(\right.$ Out $\left._{t}\right), \log \left(\operatorname{In}_{t}\right) \& r_{j, t} \stackrel{G}{\nrightarrow} \log \left(\right.$ Inequality $\left._{t}\right)$ & 4.8 & 0.31 \\
\hline
\end{tabular}

The identified series of structural China growth shocks is depicted in Figure 10. Estimating the structural shocks through sign restriction has an advantage particularly in our case. To the extent that our interest lies in the new structural mechanism with which foreign growth affects home inequality, the identification through the Cholesky decomposition might fail to accurately identify the structural shocks. However, since sign restrictions are imposed based on the prior beliefs derived from the numerical simulations, they are theoretically consist, and so the structural shocks identified in this paper should be of better accuracy.

[Figure 10 here]

The Figure 11 depicts the estimated IRFs from the sign restricted VAR with period restrictions of four quarters. The black dashed and solid lines respectively indicate the median of the IRFs with $68 \%$ bootstrapped credible bands. As noted in Fry and Pagan (2011), the median of the impulse responses in a set of admissible structural models might not accurately correspond to the true median of responses. Hence as a form of diagnostic test on the estimated IRFs, we follow their median target method to find the single impulse vector $w$ that is as close to the median responses as possible by minimizing the sum of squared standardized differences between the impulse responses. In Figure 11, median target IRFs are indicated as solid gray lines.

[Figure 11 here]

Though we see some short run deviation of median target responses from the median impulse responses, we consider this issue not to be serious in our model. This is because the median target responses share the long run dynamics with the impulse response medians 
with a reasonable accuracy for all variables. Importantly, consistent with the numerical simulations, we can infer from the IRFs that Chinese growth aggravates Japanese inequality significantly with few lags.

[Figure 12 here]

As our identification of structural shocks only involved the identification of the China growth shocks, the FEVD results plotted in Figure 12 represent the contribution of the China growth shocks with the $68 \%$ credible bands on each variable. The key finding is that Chinese growth shocks explain approximately $10 \%$ of the movement in Japanese inequality in the short run and their significance increases in the long run. These empirical results are supportive of the central hypothesis concerning the roles of external factors that affect inequality in Japan.

\section{Conclusion}

Through numerical theory we establish a behavioral association between Japan's domestic performance and its inequality and the coincidental Chinese economic growth surge. We then seek to identify this relationship in the data, with a view to quantifying the associated net effects on Japanese inequality.

The numerical simulations indicate a mechanism by which comparatively rapid foreign growth affects home inequality, via the financial channel. Domestic savings are invested in assets in a rapidly growing foreign region, motivated by higher rates of return. The profit from these higher returns is then assumed to be repatriated to home region, accruing as capital income. This, in combination with the diversion of investment from the home market and the effect of the consequent capital stagnation on worker marginal products; raises home inequality. To the extent that the foreign earnings of Japanese corporations are retained abroad for tax reasons, the repatriation of capital income may understate the growth of relative wealth, implying stronger effects than we find. The numerical simulation analysis thus captures a key mechanism behind the growth of inequality in comparatively slow-growing economies that may thus far have been overlooked in the literature.

These numerical simulation results then form a central hypothesis for testing empirically. To validate it, and to assess the significance of the effect of the financial channel on Japan's inequality, we first conduct the Granger causality tests from the estimated LAVAR, which provide some support for the hypothesis. To estimate the scale of the effect we then estimate a sign restricted VAR. The estimated IRFs show that growth in China aggravates Japan's inequality by raising the ratio of capital to total income. Furthermore, FEVDs show that the contribution of Chinese growth to Japan's inequality, thus measured, increases through time, eventually explaining up to $13 \%$. 
Figure 1: Income Share of Top Percentile (\%)

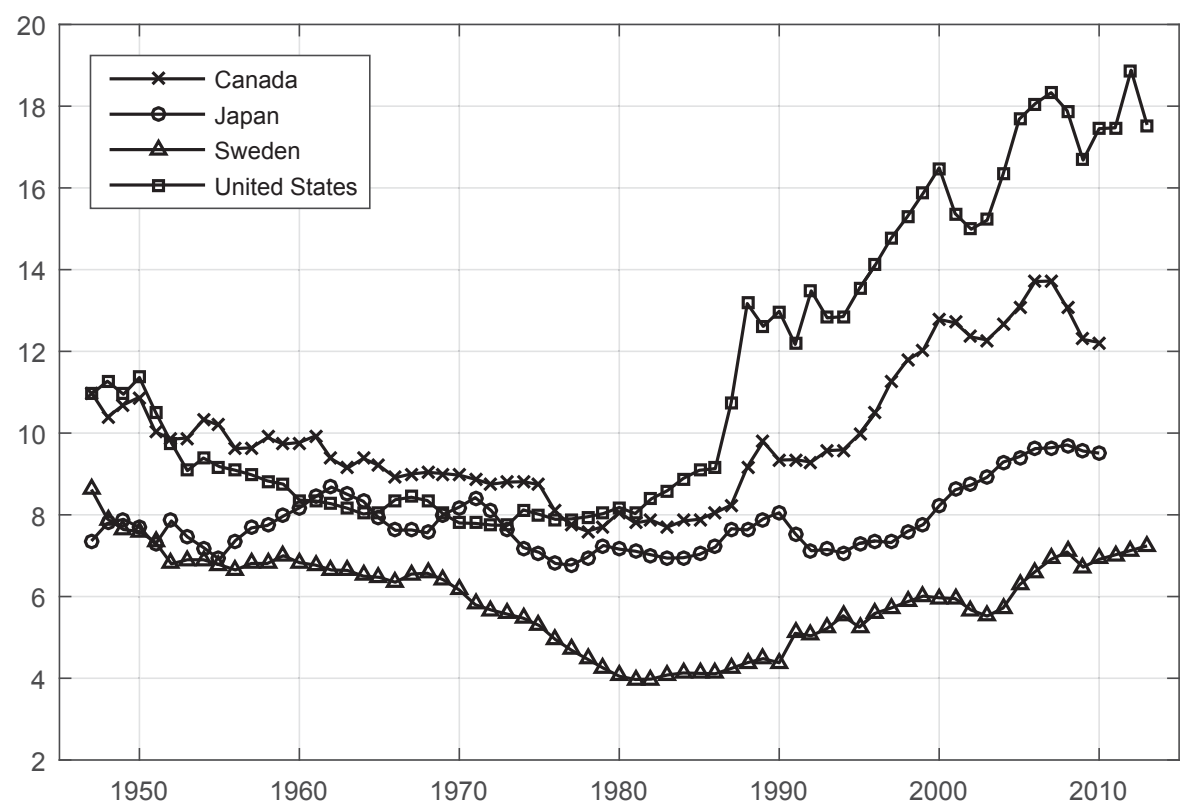

Source: The World Top Income Database and Piketty (2014), available at: http://www.wid.world/ 
Figure 2: Post-war Incomes Evolution (Yen)

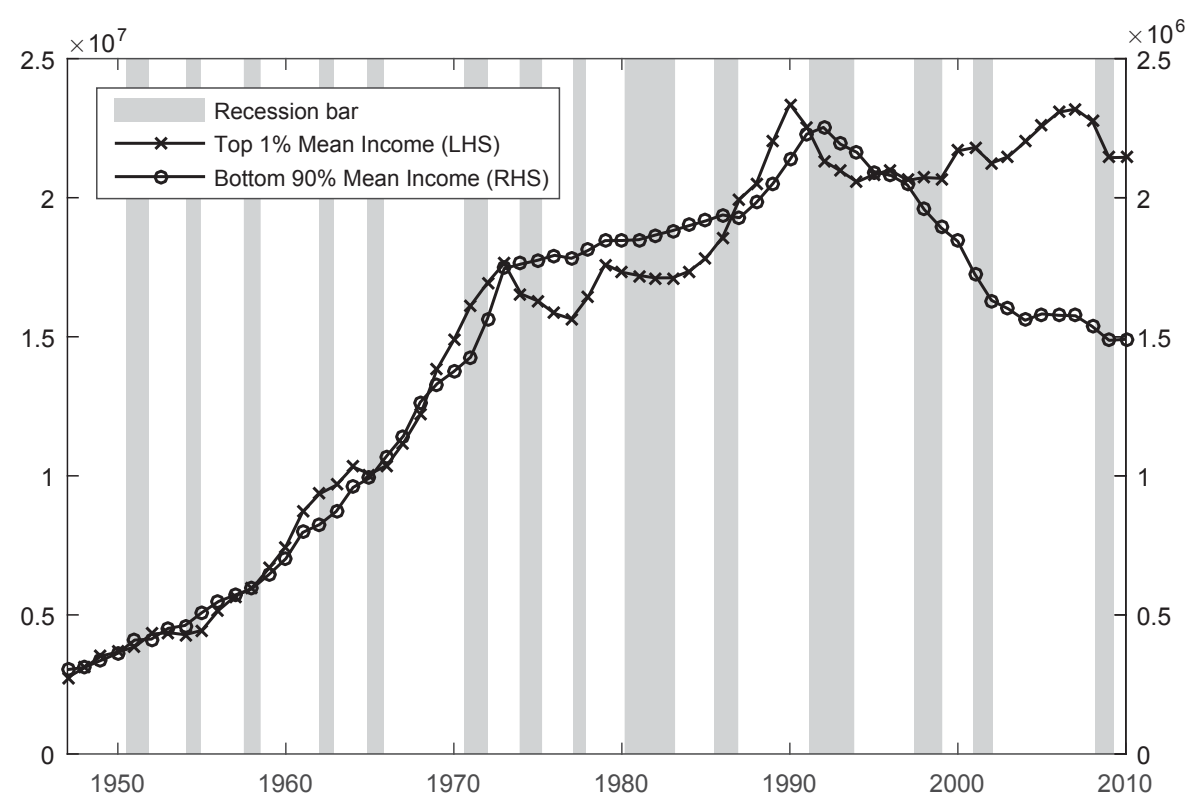

Source: Author's compilation of Moriguchi and Saez (2008) and Cabinet Office Japan 
Figure 3: Inequality: Gini (Left) and Income decile ratio (Right)
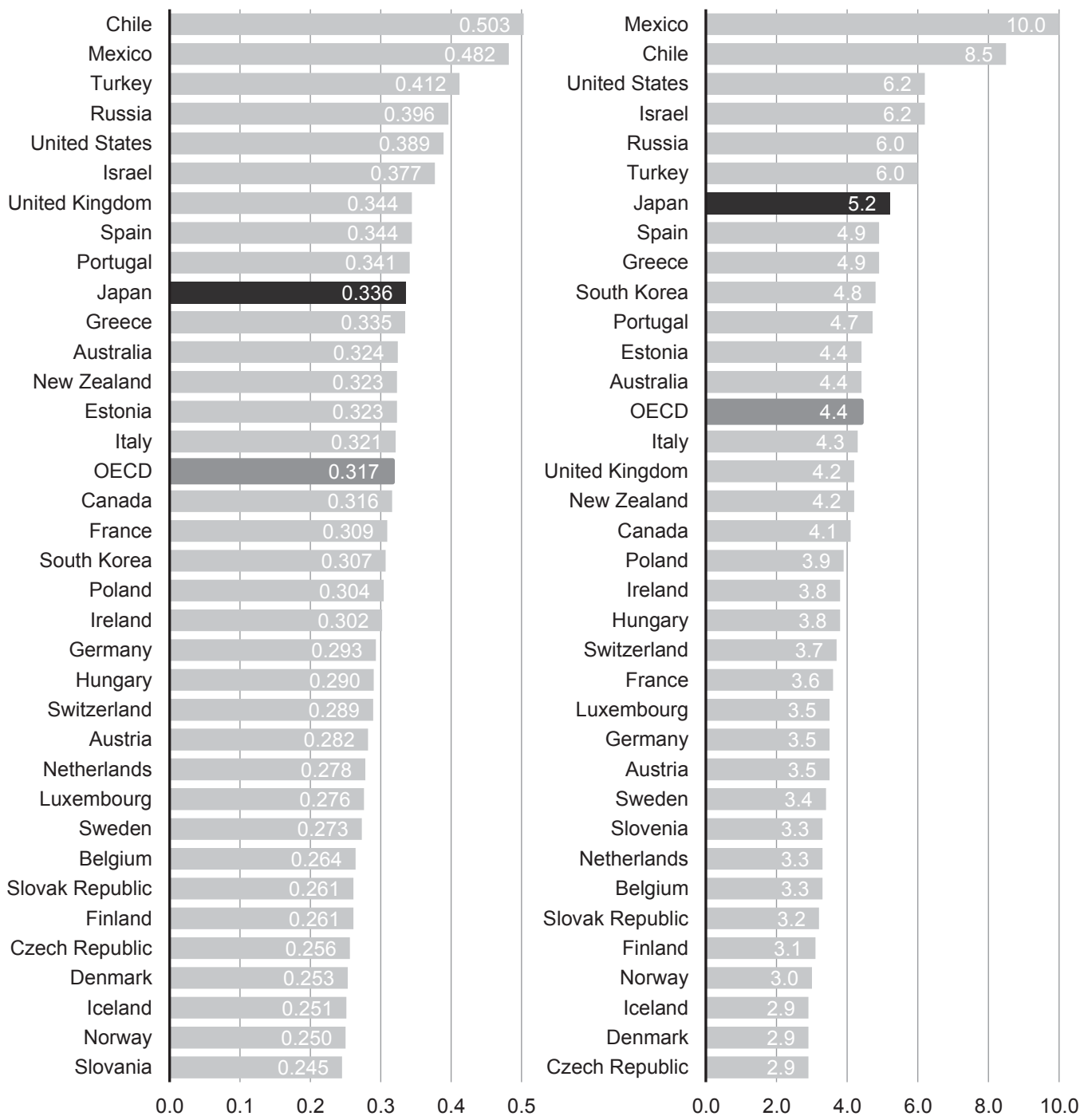

Source: OECD Income Distribution Database 
Figure 4: Composition of Japan's Trade and Global GDP (\%)
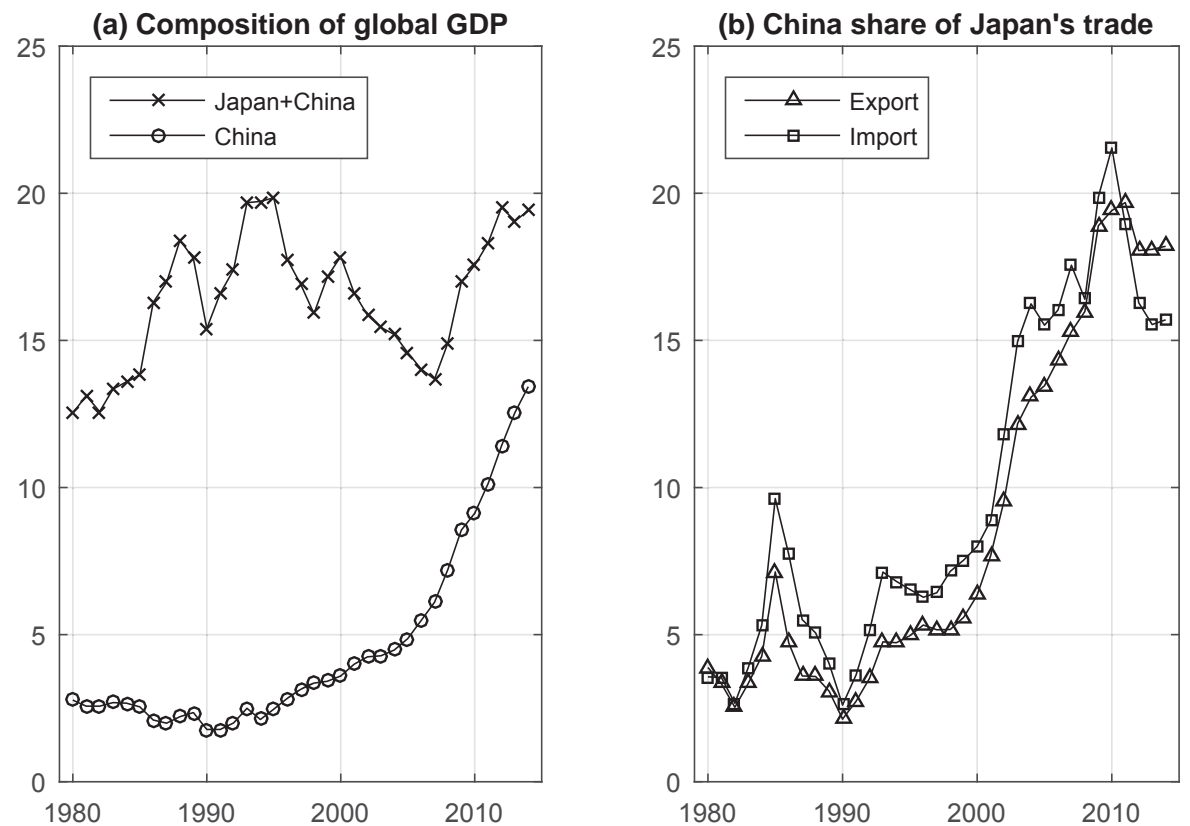

Note: Years from 1980-2014 are plotted in each graphs

Source: Balance of Payments Statistics, Statistics Bureau of Japan and IMF Economic Outlook 
Figure 5: Wealth Estimates in Trillion Yen

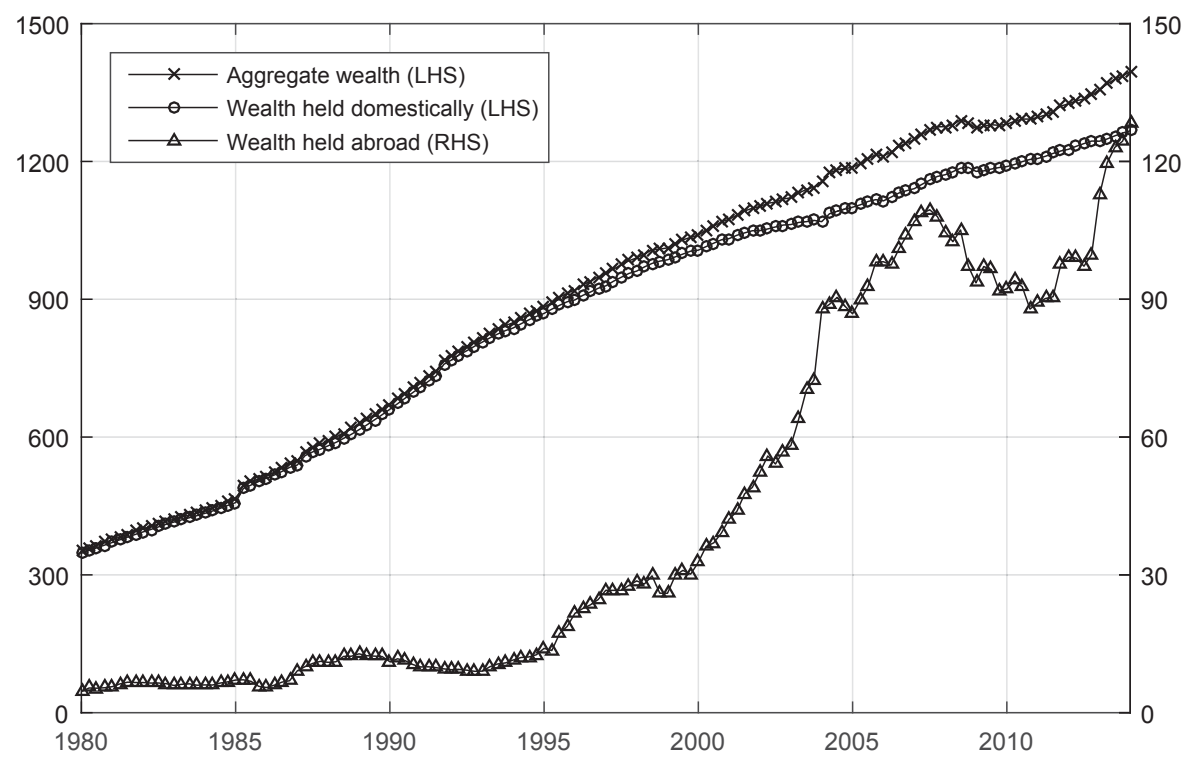

Note: This shows approximations to the values of non-housing wealth held within Japan, net of foreign holdings, and total wealth held by Japanese both at home and abroad. It is derived by combining a nominal series for the national capital stock (tangible private assets) with 1) private factor income outflows divided by the Japanese corporate bond yield to indicate foreign holdings in Japan, 2) private factor income inflows divided by the US corporate bond yield, to indicate foreign holdings by Japanese, and 3) official foreign reserves of the Bank of Japan. 
Figure 6: The Effects of Foreign Growth on Home Output and Asset Demand

(a) Real GDP

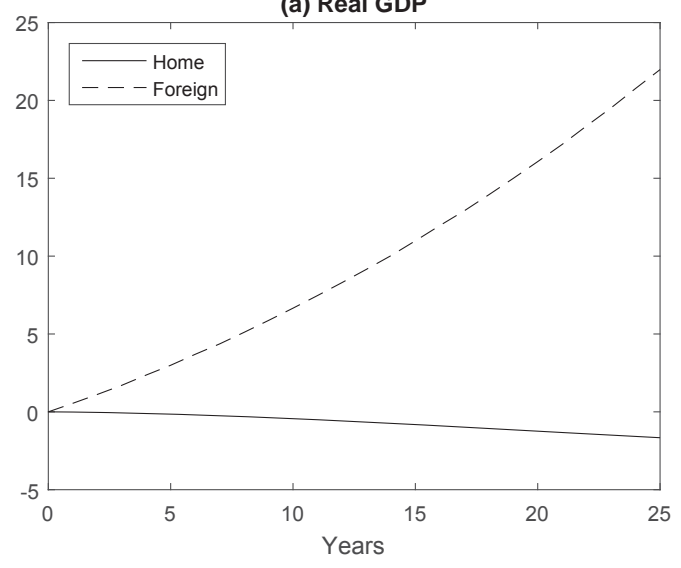

(c) Asset Demand

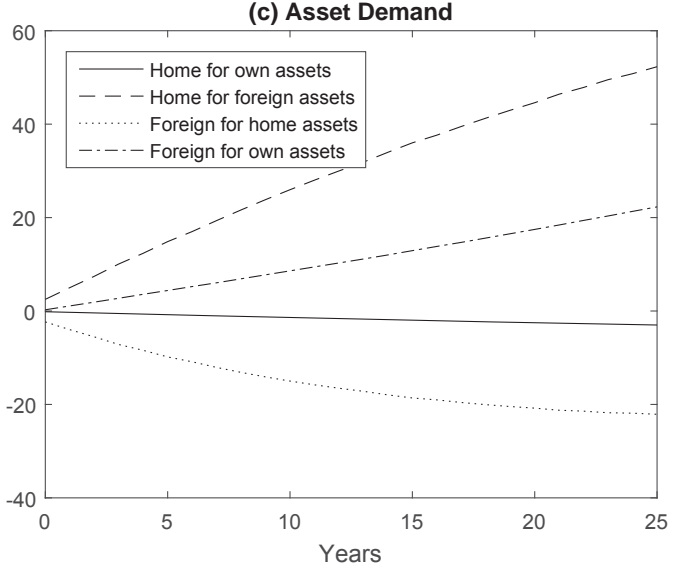

(b) Real Investment

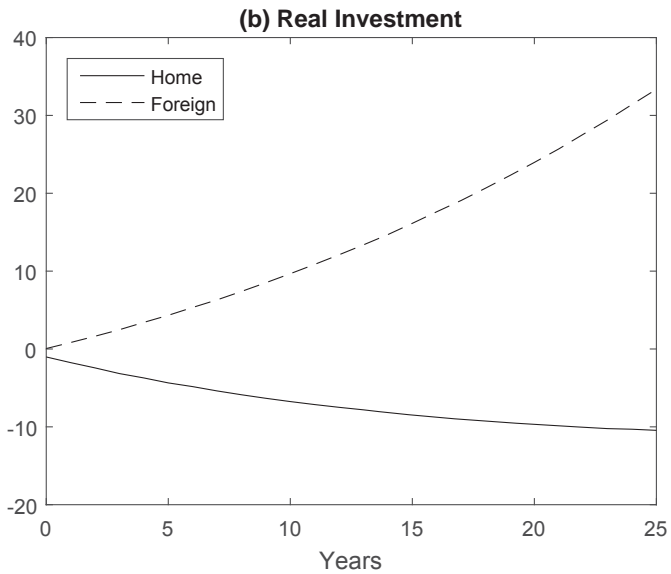

(d) Asset Ownership

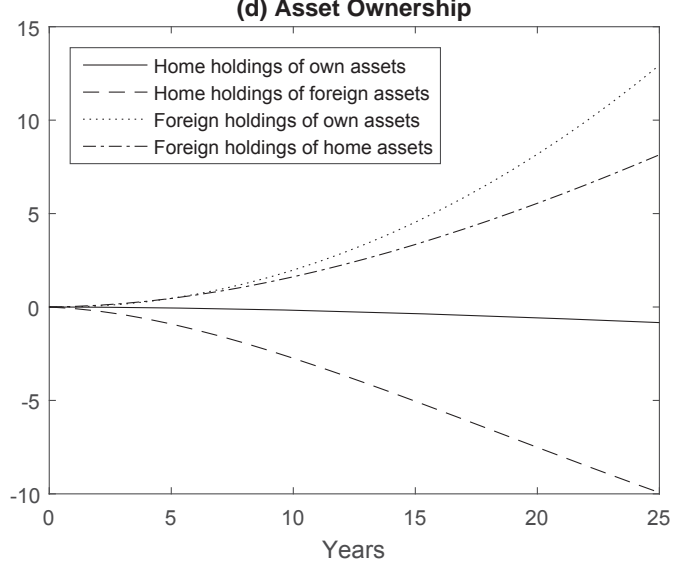


Figure 7: The Effects of Foreign Growth on Income and its Distribution
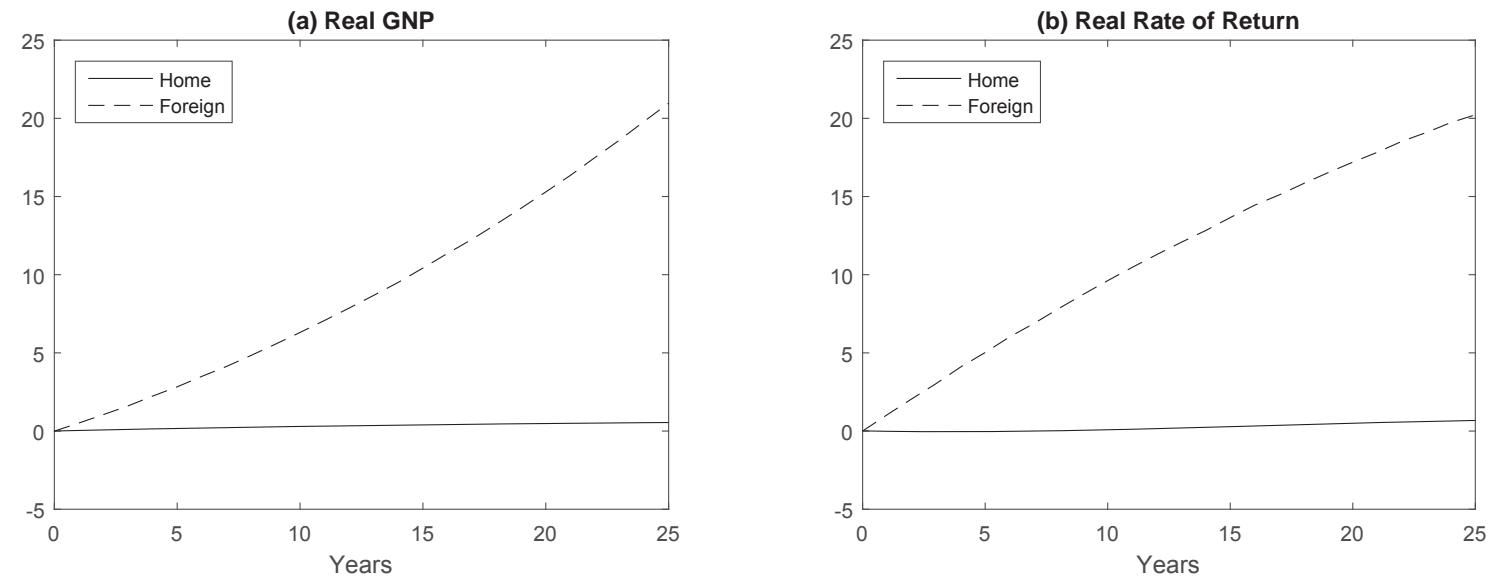

(c) Real Net Factor Income
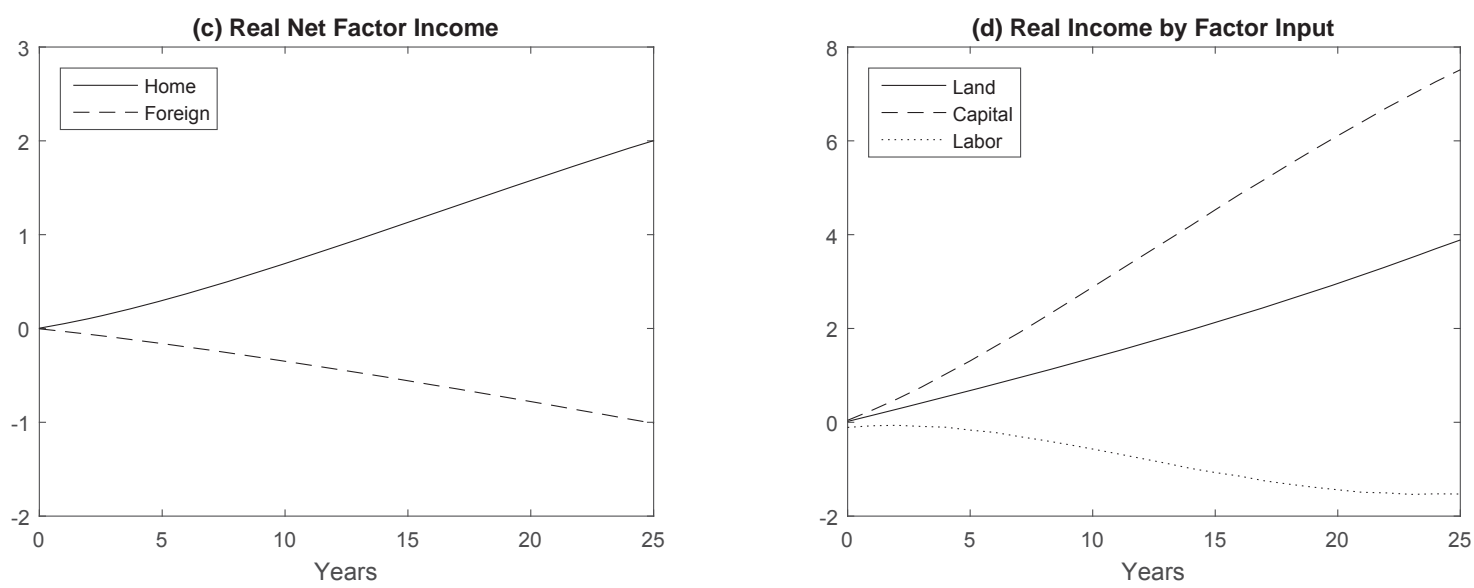
Figure 8: Stylized financial transmission mechanism

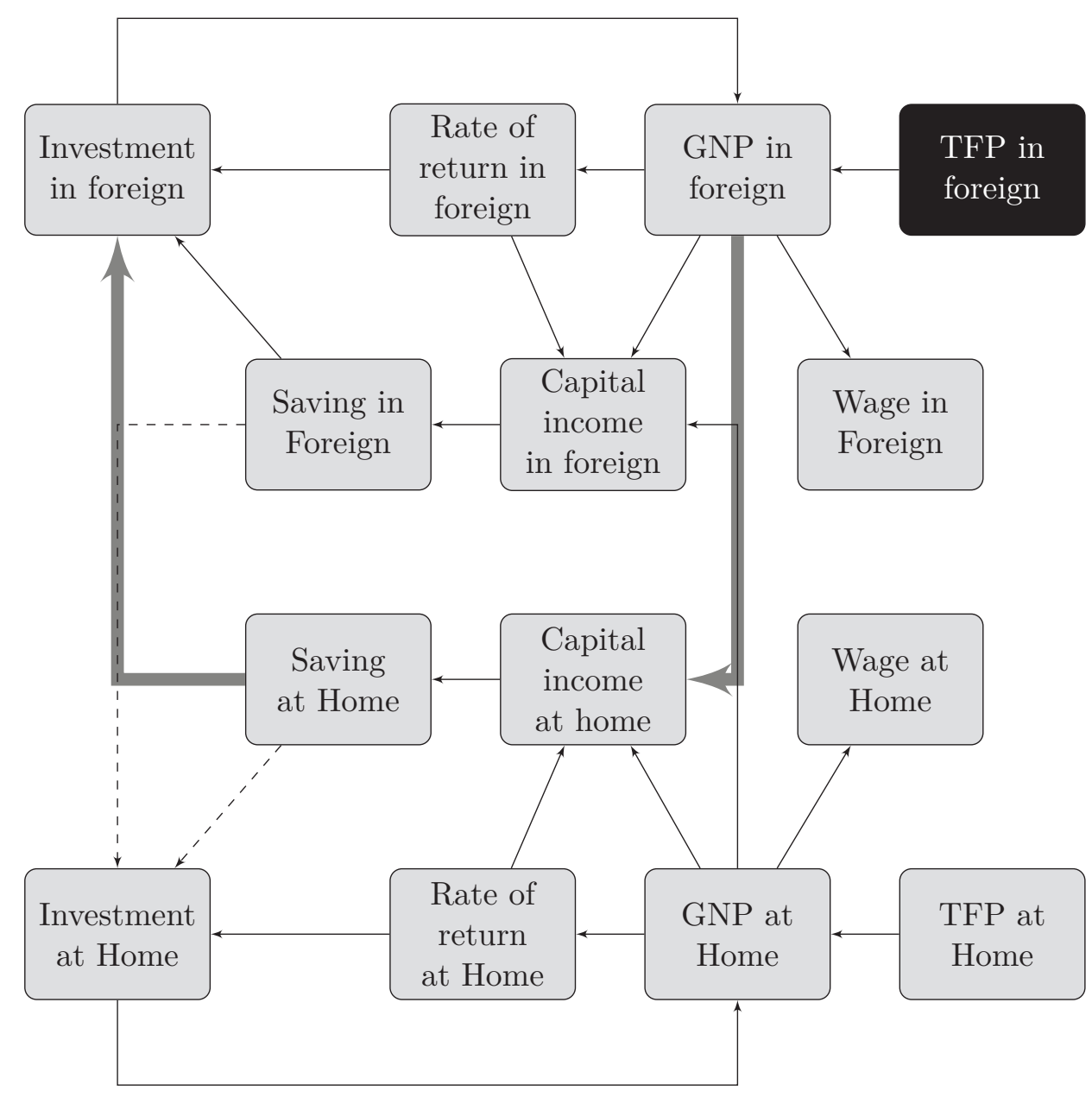


Figure 9: Data
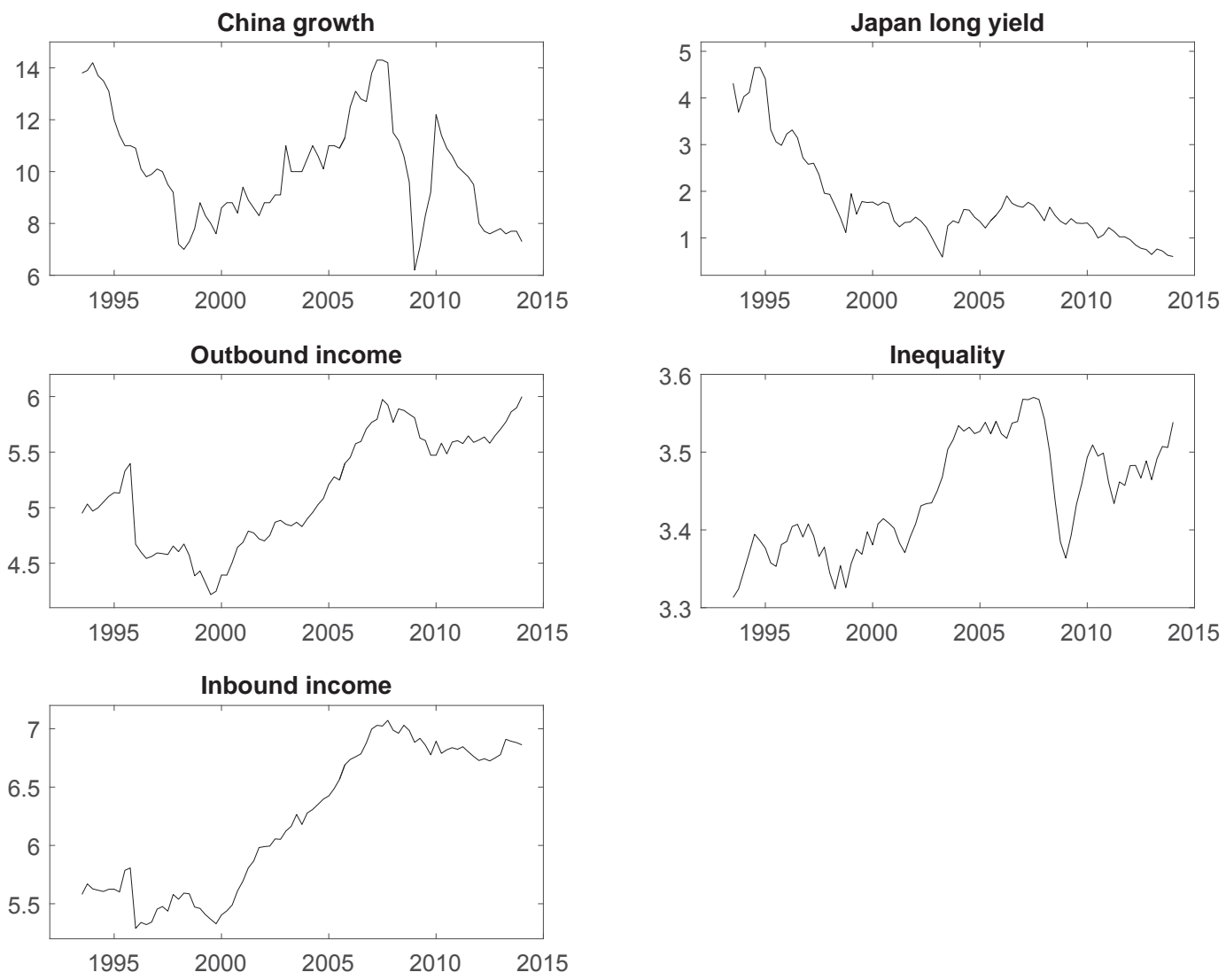
Figure 10: Series of China growth shock

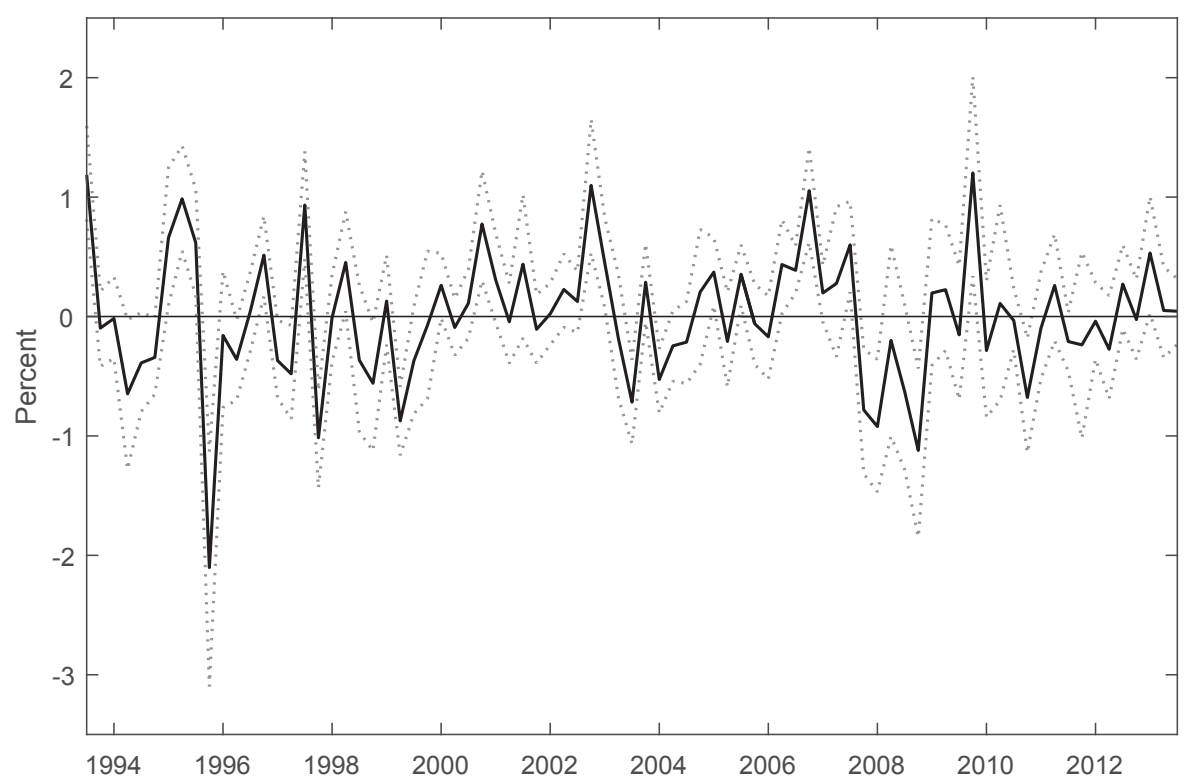

Note: The solid line shows the median of the China growth shocks and the dotted lines shows the $68 \%$ error bands. 
Figure 11: Impulse response to China growth shock
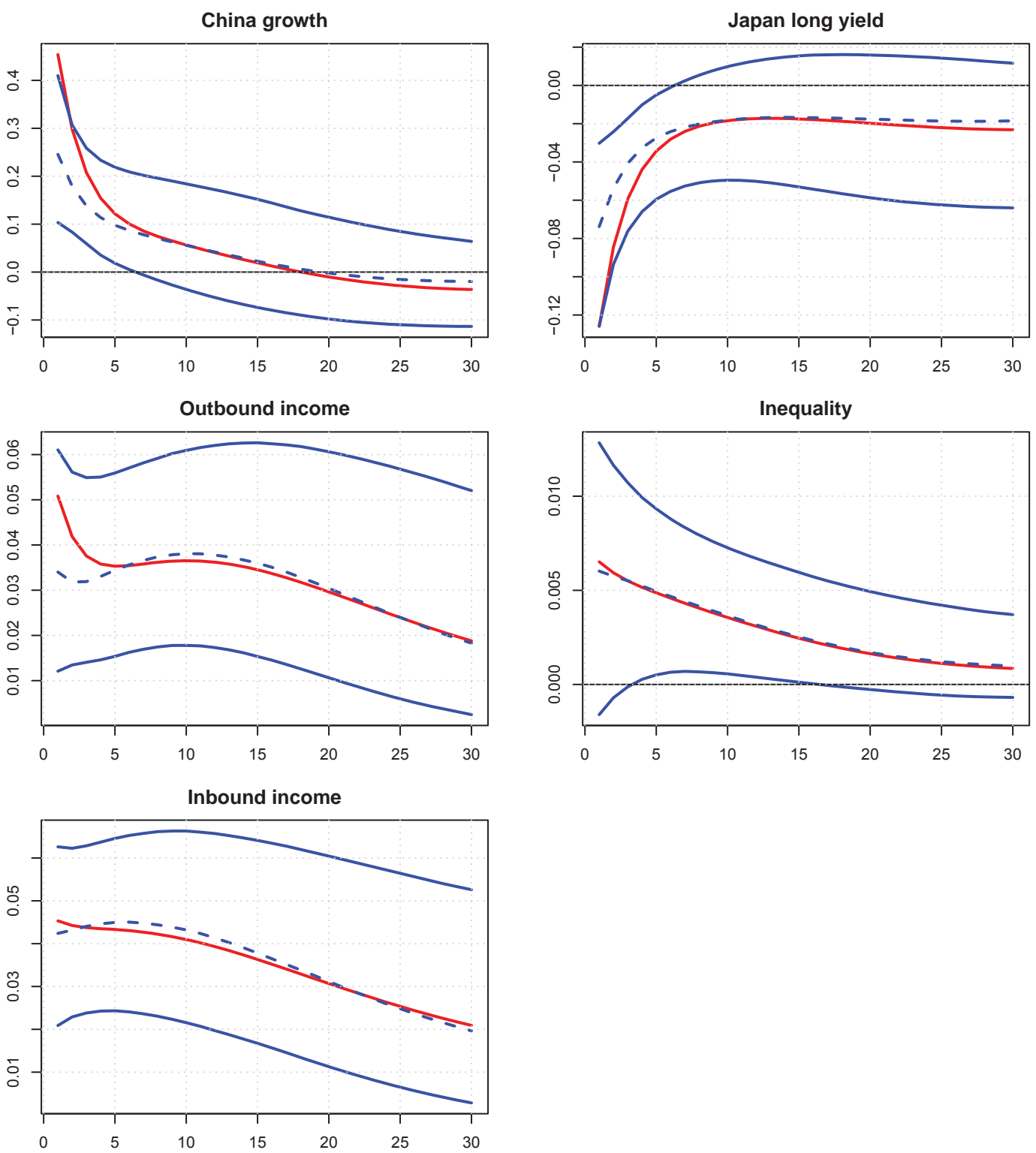

Fry-Pagan

- - Impulse response

Error bands

Note: The figure shows the IRFs estimated through Uhlig (2005)'s rejection method, where the black dashed and solid lines indicate the median of sampled IRFs and $68 \%$ credible intervals, respectively. The gray solid lines indicate Fry and Pagan (2011)'s median target IRFs that are closest to the median responses from those obtained in each admissible rotation. 
Figure 12: Forecast error variance decomposition
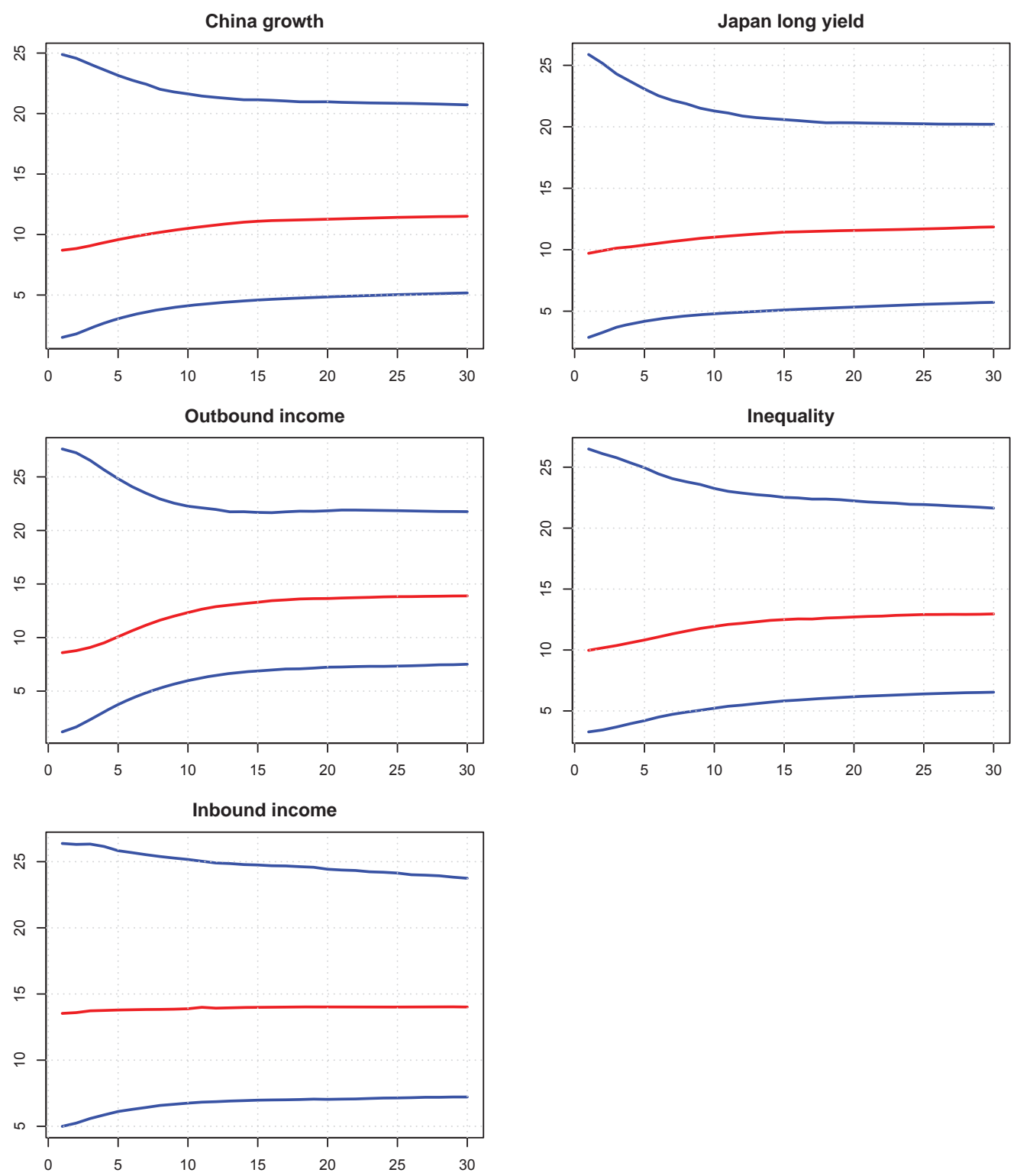

Note: Gray solid lines indicate the contribution of China growth shock on each variables with $68 \%$ standard error bands plotted in black. 


\section{References}

Alesina, A. and Perotti, R. (1996) "Income distribution, political instability, and investment", Journal of Political Economy 40 (6), pp. 1203-1228.

Armington, P.S. (1969) "A Theory of Demand for Products Distinguished by Place of Production", Staff Papers (International Monetary Fund) 16 (1), pp. 159-178.

Autor, D.H., Dorn, D., and Hansen, G.H. (2013) "The China syndrome: local labor market effects of competition in the United States", American Economic Review 103 (6), pp. 2121-2168.

Barro, R.J. (2000) "Inequality and Growth in a Panel of Countries", Journal of Economic Growth 5 (1), pp. 5-32.

Berman, E., Bound, J., and Griliches, Z. (1994) "Changes in the demand for skilled labour within US manufacturing: evidence from the annual survey of manufactures", Quarterly Journal of Economics 109 (2), pp. 367-397.

Bound, J. and Johnson, G. (1992) "Changes in the structure of wages in the 1980s: an evaluation of alternative explanations", American Economic Review 82 (3), pp. 371392.

Danne, C. (2015) "VARsignR: Estimating VARs using sign restrictions in R", Munich Personal RePEc Archive (68429).

Feenstra, R.C. and Hansen, G.H. (1995) "Globalisation, outsourcing and wage inequality", American Economic Review 86 (2), pp. 240-245.

Feldstein, M. (1995) "The Effect of Marginal Tax Rates on Taxable Income: A Panel Study of the 1986 Tax Reform Act", Journal of Political Economy 103 (3), pp. 551-572.

Freeman, R. (2010) "Does Inequality Increase Economic Output", Controversies About Inequality, Stanford, CA: Stanford University Press.

Fry, R. and Pagan, A. (2011) "Sign restrictions in structural vector autoregressions: a critical review", Journal of Economic Literature 49 (4), pp. 938-60.

Harris, R.G. and Robertson, P.E. (2013) "Trade, wages and skill accumulation in the emerging giants", Journal of International Economics 89, pp. 407-421.

Haskel, J., Lawrence, R.Z., Leamer, E.E., and Slaughter, M.J. (2012) "Globalization and U.S. Wages: Modifying Classic Theory to Explain Recent Facts", Journal of Economic Perspectives 26 (2), pp. 119-140.

Hayashi, F. and Prescott, E.C. (2002) "The 1990s in Japan: A Lost Decede", Review of Economic Dynamics 5, pp. 206-235. 
He, Z. and Maekawa, K. (2001) "On spurious Granger causality", Economics Letters 73, pp. 307-313.

Helpman, E., Itskhoki, O., and Redding, S.J. (2010) "Inequality and Unemployment in a Global Economy", Econometrica 78 (4), pp. 1239-1283.

Horioka, C.Y. (2006) "The Causes of Japan's Lost Decade: The Role of Household Consumption", Japan and the World Economy 18, pp. 378-400.

Krugman, P. (1995) "Growing world trade: causes and consequences", Brookings Papers 1, pp. $327-377$.

Kuznets, S. (1955) "Economic Growth And Income Inequality", The American Economic Review XLV (1), pp. 1-28.

Lazear, E.P. and Rosen, S. (1981) "Rank-Order Tournaments as Optimum Labor Contracts", Journal of Political Economy 89 (5), pp. 841-864.

Leamer, E.E. (1996) "Wage inequality from international competition and technological change: theory and country experience", American Economic Review 86 (2), pp. 309314 .

Lindsey, L. (1987) "Individual Taxpayer Response to Tax Cuts: 1982-1984, with Implications for the Revenue Maximizing Tax Rate", Journal of Public Economics 33, pp. 173206.

Moriguchi, C. and Saez, E. (2008) "The Evolution of Income Concentration in Japan, 18862005: evidence from Tax statistics", The Review of Economics and Statistics 90 (4), pp. $713-734$.

Nishizaki, F., Yamada, Y., and Ando, E. (1998) Nihon no Shotoku Kakusa: Kokusai Hikaku no Shiten kara (Income Inequality in Japan: An International Comparison), Tokyo: Keizai Kikakucho Keizai Kenkyusho.

Okun, A.M. (1975) Equality and Efficiency: The Big Tradeoff, Washington DC: The Brookings Institution Press.

Ostry, J.D., Berg, A., and Tsangarides, C.G. (2014) "Redistribution, Inequality, and Growth", IMF Staff Discussion Note SDN/14/02.

Piketty, T. (2014) Capital in the Twenty-First Century, Cambridge, Massachusetts: The Belknap Press of Harvard University Press.

Saiki, A. and Frost, J. (2014) "Does unconventional monetary policy affect inequality? Evidence from Japan", Applied Economics 46 (36), pp. 4445-4454. 
Sims, C.A., Stock, J.H., and Watson, M.W. (1990) "Inference in linear time series models with some unit roots", Econometrica 58 (1), pp. 113-144.

Stiglitz, J.E., Sen, A., and Fitoussi, J.P. (2009) "Report by the Commission on the Measurement of Economic Performance and Social Progress", Commission on the Measurement of Economic Performance and Social Progress Paris.

Stolper, W.F. and Samuelson, P.A. (1941) "Protection and Real Wages", Review of Economic Studies 9, pp. 58-73.

Suzuki, M., Sudo, N., and Yamada, T. (2014) Linkage between macroeconomic conditions and inequality in Japan (Preliminary), Presented at the Canon Institute for Global Studies: End of Year Macroeconomics Conference.

Tachibanaki, T. (2005) Confronting Income Inequality in Japan: A Comparative Analysis of Causes, Consequences, and Reform, Cambridge: MIT Press.

Toda, H.Y. and Phillips, P.C.B. (1993) "Vector Autoregression and Causality", Econometrica 59, pp. 229-255.

Toda, H.Y. and Yamamoto, T. (1995) "Statistical inference in vector autoregressions with possibly integrated processes", Journal of Econometrics 66, pp. 225-250.

Tokarick, S. (2005) "Quantifying the impact of trade on wages: the role of non-traded goods", Review of International Economics 13 (5), pp. 841-860.

Tyers, R. (2012) "Japanese Economic Stagnation: Causes and Global Implications", Economic Record 88 (283), pp. 517-536.

- (2015) "International effects of China's rise and transition: neoclassical and Keynesian perspectives", Journal of Economics 37, pp. 1-19.

- (2016) "Slower growth and vulnerability to recession: updating China's global impact", Scottish Journal of Political Economy 66 (1), pp. 66-88.

Tyers, R., Duncan, R., and Martin, W. (1999) "Trade, technology and labor markets: general equilibrium perspectives", Journal of Economic Integration 14 (2), pp. 226-264.

Tyers, R. and Yang, Y. (1997) "Trade with Asia and skill upgrading: effects on labor markets in the older industrial countries", Review of World Economics 133 (3), pp. 383-418.

Uhlig, H. (2005) "What are the effects of monetary policy on output? Results from an agnostic identification procedure", Journal of Monetary Economics 52, pp. 381-419.

Winchester, N. and Greenaway, D. (2007) "Rising wage inequality and capital-skill complementarity", Journal of Policy Modeling 29 (1), pp. 41-54.

Wood, A. (1994) North-South Trade, Employment and Inequality, Oxford: Clarendon Press. 
Zivot, E. and Andrews, D.W. (1992) "Further Evidence on the Great Crash, the Oil-Price Shock, and the Unit-Root Hypothesis", Journal of Business 8 Economic Statistics 10 (3), pp. 251-270. 